\title{
Research on the Problems of Corporate Sales Fraud Audit
}

\author{
Shouchun Xiong \\ School of business \\ Huaiyin Institute of Technology \\ Huaian, China \\ Xiongsc111@sina.com
}

\author{
Ming Zhou \\ School of business \\ Huaiyin Institute of Technology \\ Huaian, China \\ yiwenw@163.com
}

\begin{abstract}
With the development of The Times, sales fraud has become an important means of enterprise operation profit, the accounting and auditing is becoming more and more cause the attention of the public. Article on the base of the current sales fraud audit in our country, analysis of the sales fraud means and causes of sales fraud audit are discussed and the existing problems, by strengthening the professional caution of the audit, a targeted program, improve the quality of the CPA profession and other aspects of analysis, and on how to improve the sales fraud audit quality put forward their own views and opinions.
\end{abstract}

Keywords-sales fraud audit; professional care; audit procedures; CPA Quality

\section{INTRODUCTION}

Corporate sales and profits is a key measure of financial performance, but also an important evaluation index core earnings quality companies, with business risk continues to increase, while poor business performance, management fraud to regulate the sale of profits will more and more the case. Although sales fraud forms and means endless, but ultimately no more than two situations: one is to obtain in order to achieve maximum benefit and use tax, that means the reduction in income taxes; the other is to achieve a particular purpose, use means whitewash financial statements, such as the various means of bank loans, allotment of new shares, or try to manipulate stock prices and inflated revenue raised leaving the profits obtained. Which causes the risk of material misstatement in the financial statements is increased, but also to the CPA audit work has brought great risks and challenges, strengthen sales fraud audit, to curb the incidence of fraud and lower sales of CPA audit risk has very important.

\section{The Status of SALES FraUd AND AUdiT}

Chinese and foreign listed companies, a large number of cases of fraud involving sales, which more famous Chinese red Industrial Company, Tianjin Guang Xia (Group) Co., Windaus salad oil companies, equity funds, ZZZZ 100 Lancaster, Faer Mo companies and McKesson \& Robbins company. These companies planned fraud scheme to bring a lot of CPA audit risk.

In early 2008, China Aerospace Science and Industry Corporation Liuzhou Changhong machinery manufacturing company audit conducted in 2002 company annual audit found that such an anomaly: the company in 2001, 2002 , civilian sales were 45.63 million yuan, 53.23 million yuan, rise trends; financial reflect the number of waste materials sales were 863 tons, 510 tons, of waste materials income sales were 780,000 yuan, 450,000 yuan, a downward trend. Under normal circumstances, scrap and other waste materials in the production process should take place with the same proportion of the scale of production growth or decline, but the financial data Liuzhou Changhong machinery manufacturing company is not reflected in reasonable proportion trend. With the case of doubt, the audit office supplies recycling of waste materials at the company, sales and receivables carried on the key audit. Isolated together result is fairly typical sales fraud.

Although China's CPA industry has developed rapidly, audit quality has improved greatly, but because of the late start, poor foundation, compared with Western countries, there is still a wide gap between audit qualities, sales fraud audit is no exception. Since 1993, prudential events wilderness event, Qiongminyuan event until caused great shock Guangxia events, all with the CPA audit failures related. SFC investigation of listed companies each has a corresponding false disclosure behind accounting firms and CPAs punished.

To China in 1994 and 2007 has 137 listed companies suspected of selling fraud study found that the presence of corporate sales fraud following characteristics: First, the smaller companies of fraud and poor profitability before fraud; manufacturing, agriculture and information technology industry is a fraud company relatively concentrated industries; higher economically backward areas the proportion of company fraud; Second, China's high proportion of the outstanding shares of the company fraud; shareholders' meeting attendance is low; the number of the Board of Directors more; ownership concentration low; the largest shareholder of control is low; the higher the number of shares executives; the lower the average age of executives; the higher the proportion of male members of senior management; Third, the revenue recognition issue is our biggest sales fraud "disastrous", and the use of related party transactions and assets reorganization of fraud is a major feature; four listed companies of huge amount of fraud, longer duration, and a significant proportion of fraud or companies listed in the premarket after a short implemented within the fraud; Fifth, the proportion of fraud companies were registered accountants found very low; a high percentage of fraud during the 
company had to replace the accounting firm of fraud; Sixth, the number of companies subject to regulatory penalties showing a significant increase every year trend, but the penalty period is longer; Seventh, high fraud companies were ST, suspend or terminate the listing listed proportions; Eighth, of regulatory penalties for fraud in the company's main "criticism and education" which, by the probability of substantial punishment rarely.

\section{SAles Fraud Auditing Problems}

\section{A. Sales Audit lack of attention.}

In the plan the audit stage, when executed, initial operational activities of the audited entity, should be concerned about its sales, and analyze their risk of material misstatement, on this basis, to reflect the purpose and requirements of sales fraud audit in the audit plan, lest make sales during the audit fraud become the forgotten corners; in the audit of the implementation phase, to determine whether the implementation of the sales transaction cycle control tests depending on the circumstances, focusing on how the implementation of virtual testing, as well as the requirements to obtain audit evidence, worthy of note that, given the sales business fraud and greater risk of multiple features, it should analyze procedures to identify fraud risk areas and larger scope, and its detailed audit; the audit report stage, forming the audit opinion, the auditor shall evaluate whether in general to obtain sufficient appropriate audit evidence to reduce the risk to an acceptably low level. When finishing the analysis of audit evidence to form an opinion, we should take full account of the results of the audit of sales fraud, in order to improve the accuracy of the audit findings ${ }^{[1]}$.

\section{B. Failure to carefully controlled tests.}

Compliance testing refers to the auditors on the basis of the audited entity internal control initial evaluation on to confirm that the control is in the practical work to be implemented, the implementation of the practical effect of compliance testing activities to establish the control of mind and carried out. Through the implementation of an effective compliance test can determine whether sales of internal control deficiencies, and for sales to determine substantive defect inspection focused, targeted to improve the substantive tests. CPA in the audit practice tend to ignore sales compliance testing, or be a mere formality, it failed to implement effective inspection of the relevant critical control points ${ }^{[2]}$. For example, the link again to accept orders, failed to customer and client list be checked, will probably sell to an unauthorized customer; in approving credit, failed to check whether the signature on the credit department of sales orders, may bear undue credit risk; in press sales orders were shipped, shipping cargo, shipping certificates and failed to sell a singlephase check, you may experience the issue, the shipment may not match with the ordered goods or unauthorized issue; in billing to the customer, the sales invoices failed to conduct an independent review of inspection may occur for fictitious transactions or duplicate billing for billing, and some may not be billed shipment document that is possible valuation and sales invoices errors and other circumstances; when record sales, invoices may not be the single billing and customer accounts, invoices may pass over to the wrong customer account. When handling and recording cash, income from bank deposits, money funds possible theft, receiving record error and so on.

\section{Failure to implement targeted substantive testing}

Substantive program refers to the CPA for the assessment of risk of material misstatement in order to direct the implementation of the audit process found a material misstatement at the assertion level. Thus, the CPA should be designed and implemented substantive procedures for assessment of risk of material misstatement in order to find material misstatement at the assertion level. Substantive program includes all types of transactions, account balance, details of tests and presentation of substantive analytical procedures ${ }^{[3]}$. Sales in substantive testing, the auditor general tend to impose audit procedures, from the authenticity, completeness, timeliness, accuracy valuation, disclosure and other aspects of the compliance check, while ignoring the implementation of the sales fraud targeted audit procedures, for example, that is not true for sales in advance of confirmation, omission, namely to postpone sales confirmation, repeat billing sales, sales returns and allowances use to regulate the business of sales, and even fictitious sales, etc., CPA is often lacking due professional care, failed to sales during the audit found evidence of fraud has to do due attention, it did not take further audit procedures to obtain sufficient and reliable audit evidence, part of the CPA audit have also just published an opinion on the legality and fairness of the financial statements, there is no specific obligation to discover the concept of fraud, which is bound to audit the quality of work.

\section{Poor audit staff professionalism}

Audit quality depends largely on the audit of the main Quality certified public accountants, sales of fraud audit quality is not high is also closely related to the quality of the CPA is not high. This is mainly reflected in the following two aspects: on the one hand, the auditors poor ethics, fraud in the sale to confirm the audit process, due to increased competition and market disorder tends to ignore the CPA professional ethics and their independence from vulnerable interference such as economic interests, relationships, external pressures and other factors, leading to its audit process can not maintain proper independence and professional skepticism, and some even found problems with the CPA customer sales fraud in the audit process, for their own interests, and it will not be disclosed in the audit report, and even complicit with it. SFC investigation of listed companies each has a corresponding false disclosure behind accounting firms and CPAs punished. In these events, some CPA not only failed to exercise due professional care, do to reveal errors and shortcomings of the audit responsibilities, some even with the management of listed companies, "conspiracy", issued by the audit report seriously inaccurate, not only their professional independence lost, but also seriously undermined investor confidence in the entire accounting profession, and on the other hand, auditors professional service quality is not high, in today's knowledge 
explosion, sales fraud forms of business and more and more, the amount involved is also growing, more and more sophisticated means of fraud, fraud audit to make sales, not only requires auditors to acquire the appropriate audit knowledge and technology, but also to be familiar with the knowledge and technology-related marketing fraud, such as relevant marketing knowledge, namely import and export tax knowledge, credit and billing information, etc. However, China's current auditors, although constantly for their "oxygenated" professional qualities and skills are improved, but, according to sales fraud particularity targeted sales fraud audit professionals also yield less ${ }^{[4]}$. Since the education, expertise, experience, personal factors and other reasons, resulting in most of the auditors do not have the capability of special audits. This will certainly affect sales fraud audit work quality and efficiency; we can not guarantee the effectiveness of the audit healthy play.

\section{StREngthen SALES FraUd AUditing StRATEgIES}

\section{A. To strengthen the focus on sales fraud audit, fraud audit emphasis on sales}

In the plan the audit stage, when executed, initial operational activities of the audited entity, should be concerned about its sales business fraud, and to analyze the risk of material misstatement, on this basis, reflecting sales fraud audit purposes and requirements in the audit plan, lest make sales fraud has become a forgotten corner in the audit process; the implementation phase of the audit, to determine whether to implement sales fraud control tests focus on how the implementation of virtual testing, as well as the requirement to obtain audit evidence depending on the circumstances, worth noting that, given the sales business fraud and greater risk of accidental characteristics, when its implementation details of the test should not be used audit sampling methods, but should conduct a detailed audit; the audit report stage, in forming the audit opinion, the auditor shall overall evaluation whether to obtain sufficient appropriate audit evidence to reduce the risk to an acceptably low level. When finishing the analysis of audit evidence to form an opinion, we should take full account of the results of the audit of sales fraud, in order to improve the accuracy of the audit findings.

\section{B. To strengthen sales fraud compliance testing}

CPA should do the checks on the following key points to verify the internal control system of the sales cycle: audit institutions in accepting customer orders may need to sell to the customer's terms of unauthorized conduct prevention, it is the key to control the main point in determining the customer on the customer list has been approved and approved each time unilaterally on sales; in billing to the customer, the need for possible fictitious or duplicate billing transactions for billing, and some may not have the shipment document billing, sales invoices may prevent pricing errors in three areas, each invoice shall be well associated with it and the shipment document approved sales orders, each shipment document shall be associated with it and a separate sales invoices staffing sales invoices for internal verification of critical control points; while recording sales, invoices may need to enter sales orders and customer invoices bill might pass over to the wrong customer account aspects of prevention, good sales invoices and sales account and customers the same amount posted, send regular monthly statements to customers the key point; in the process of recording cash and bank deposits, to prevent the theft of good monetary funds, payment records errors, the best use of remittance advice, independent inspection into the Union posting amount and consistency of daily cash summary, periodically prepare bank reconciliation table.

\section{Improve sales fraud substantive testing}

Targeted test program execution. Sales fraud audit, its audit procedures in addition to performing regular audits, should be based on the characteristics of fraud sales take targeted audit procedures, focus on examination of the following key points to ensure audit quality: first, to review the actual sales fraud and integrity by checking for sales orders, invoices, sales invoices and other related original documents, sales verification on whether the book actually happened, whether sales occurred in all the accounting treatment in a timely manner, whether there should be deemed sales and processing business whether the guidelines require processing, in particular, should be concerned about the existence of fictitious sales; second, sales were off testing to verify its recorded time is correct, to confirm the principle of strict accordance with the sales, check for confirmation by advancing or retarding the loss of sales to adjust phenomenon; third, with special attention to the existence of related party services, check the prices and sales conditions for the existence of abnormal situations or apparent anomaly, to prevent the use of related party transactions adjust fraud means profits; fourth, focus on sales return, sales allowances and discounts business, check whether such operations actually happened, whether authorized approval, whether goods or withdraw the allowances and discounts truthfully presented to the buyer, if there are private Let coffers of law and discipline phenomenon.

\section{To improve the professional quality to ensure audit quality}

Improve the quality of auditors is the basis for sales fraud audit quality, auditors need to keep proper independence and professional prudence, which is mainly from the following two aspects: on the one hand, to improve the professional ethics of the audit, by occupation moral constraints and industry regulation, supplemented by increased compliance costs, prompting auditors sales fraud audit process, to maintain proper audit independence, abide by professional ethics, be able to resist the temptation to interfere with economic interests and external pressures, to maintain due professional care, the implementation of standardized audit procedures for the issue of disclosure during the audit found that the disclosure of the adjustment should be required to adjust the audited entity, and according to the importance of the audited entity and attitude problem determination issued the type of audit opinion; on the other hand, the auditor should work hard to continuously improve their professional quality, familiar with the sale of various fraud-related knowledge, not 
only should have regular audit techniques and knowledge should be combined with specific sales fraud control features , targeted audit techniques to ensure the discovery of fraud sales business problems to reduce audit risk, audit quality assurance, to meet its "economic police" role.

\section{CONCLUSION}

In view of the strong preference profit motive and sales fraud is the main means of profit manipulation, the risk of material misstatement at present most of the enterprises in China have higher sales, sales audit has become the focus and key audit of accounting statement. To ensure the quality of sales audit, the audit staff must first pay attention to the audit business, to do its occupation cautious, be skeptical, attention and find sales fraud business, strictly enforce the "presumption of fraud" principle; secondly, the registered accountants should be combined with the characteristics of sales, targeted the audit procedures, focus on and find sales fraud; finally, the auditor should change with the development of social economy, environment and audit methods and laws and regulations, improve the quality of their own, must abide by the professional ethics and maintain independence, but also continuously improve the professional competence, should be in a variety of fraud means companies may appear the full understanding is the basis of knowledge and experience, continue to strengthen the audit work, to ensure the sales business fraud audit Quality.

\section{ACKNOWLEDGMENT}

This article is an important part of the Huai'an policy guidance project (HAR2015007), in this to the project team members to express my heartfelt thanks!

\section{REFERENCES}

[1] Xiaohui Li. Audit laboratory[M]. Economic Science Press, 2012.6

[2] Jiang Wu. Based audit[M]. Higher Education Press,2012.7

[3] Shouchun Xiong. Well Reflections Availability Audit and Accounting Monthly. Accounting and accounting. 2006,12 (31): 48-52

[4] Jianhua Li. CPA audit inventory should pay attention to the financial and economic problems[M], 2008, 23 (16):178-18 